\title{
An Improved Mobile Trolley for Satellite Test Facility
}

\author{
[Elena Woo Lai Leng]
}

\begin{abstract}
A mobile trolley is a form of mechanical ground support equipment that allows engineers to perform integration work at various parts of the satellite body in a safe manner, thus preventing mishandling of the satellite. Existing mobile trolleys available in the market have several limitations, whereby its height is not adjustable and typical mobile trolley doesn't have any mechanism to transport a satellite into the thermal vacuum chamber to undergo environmental test. Therefore, this project was proposed to design and develop a Motorised Adjustable Vertical Platform (MAVeP), an improvement to existing mobile trolleys, which has the ability to move around, to increase or decrease its height and finally, to be able to transport the satellite into the thermal vacuum chamber. The MAVeP is expected to provide assistance in the assembly, integration and testing operation without jeopardizing the safety of the spacecraft.)
\end{abstract}

Keywords - satellite trolley, satellite testing, mobile platform, mechanical ground support equipment

\section{Introduction}

All satellites required vigorous testing before it can be launched into space due to the huge environmental impact, both while on earth and in space [1] where the vibroacoustic effect during launch and electromagnetic and thermal effect in space environment may damage the satellite even before it begins its lifetime $[1,2]$. In order to shield itself from these impacts, the satellite has to undergo various kinds of tests, such as, vibration test, acoustic test, electromagnetic test and thermal vacuum test. These tests are important to ensure the satellite achieves all the design, performance and quality requirements before it faces the worst conditions in orbit [3].

These tests are typically performed in an Assembly, Integration and Test (AIT) facility, which is a cleanroom of Class 100,000 according to ISO 14644. A test campaign for a satellite occurs before launch and could take between two (2) weeks minimum, and up to months, depending on the complexity of the project. During the test campaign, various kinds of ground support equipment are used, both mechanical and electrical. One of the distinctly noticeable mechanical ground support equipment is the mobile trolley. The satellite placed in the AIT facility is being transported around the facility via overhead crane or mobile trolley [4], with the latter being favoured mode of transport as it allows engineers to perform integration works on various parts of the satellite as well as setting up the satellite for test.

Elena Woo Lai Leng

National Space Agency of Malaysia (ANGKASA)

Malaysia
However, existing mobile trolleys or satellite trolleys are limited in terms of mobility and height, whereby existing trolleys are only able to perform rotation and translation from vertical to horizontal position or vice-versa. A satellite trolley that is able to move up or down is normally found embedded in the floor and does not have the mobility function. Therefore, this project is to improve existing design of a mobile trolley and develop an enhanced trolley that will be mobile and its height adjustable. Since this trolley will be used to transport the satellite into the thermal vacuum chamber, an additional functionality is required of the trolley, which is the telescopic function. This telescopic function is used to push the satellite from the trolley into the thermal vacuum chamber. This improved mobile trolley is given the name Motorized Adjustable Vertical Platform (MAVeP).

This project is funded by Ministry of Science, Technology and Innovation (MOSTI) (Grant No: PKA0514E006), and it is a joint collaboration between the National Space Agency of Malaysia (ANGKASA), Universiti Putra Malaysia (UPM), International Islamic University of Malaysia (IIUM) and SIRIM Machinery Technology Centre. The development of MAVeP will help researchers and engineers to gain knowledge on design of structure, control, automation and integration process as well as material selection and thus, increasing skills in designing mechanical ground support equipment (MGSE) for a satellite project.

This paper is organized as follows: Section II will present the structural and control design requirements for MAVeP, Section III will provide the analysis results; and Section IV will provide the conclusion, future work, acknowledgement and references.

\section{MAVeP Structural and Control Design Requirements}

The design of MAVeP platform is based on the structural requirements set earlier, and the task to design the platform is undertaken by UPM, led by Dr. Mohamad Ridzwan Ishak. The design of the platform structure has to take into consideration the cleanroom environment, amount of space surrounding the thermal vacuum chamber, operational requirements and maximum load that can be supported by TVC. The design requirements for platform structure is summarized in Table I below

As for the control system of MAVeP, it is the system that controls the movement of the platform. IIUM, under the guidance and leadership of Associate Professor Dr. Salmiah Ahmad, had been tasked to design the control mechanism for MAVeP which includes moving the MAVeP forward and backward, up and down as well as telescopic movement. 
Proc. of The Fifth Intl. Conf. On Advances in Mechanical, Aeronautical and Production Techniques - MAPT 2016 Copyright (c) Institute of Research Engineers and Doctors, USA .All rights reserved.

ISBN: 978-1-63248-090-3 doi: 10.15224/ 978-1-63248-090-3-49

The requirements for control system is summarized in Table II below:

TABLE I. PLATFORM STRUCTURE

\begin{tabular}{|c|c|c|c|}
\hline No. & Parameter & Specification & Remarks \\
\hline 1. & $\begin{array}{l}\text { Platform } \\
\text { Length }\end{array}$ & $\begin{array}{l}\text { Platform Deck: } \\
\text { 4,000mm } \\
\text { (minimum) }\end{array}$ & $\begin{array}{c}\text { Deck Size: } \\
\text { Baseplate Size } 2 \mathrm{~m} \text { with } \\
\text { Operator Area 1m (Front } \\
\text { and Back) }\end{array}$ \\
\hline 2. & Width & $\begin{array}{l}\text { Platform Deck: } \\
\text { 3,500mm } \\
\text { (maximum) }\end{array}$ & \\
\hline 3. & $\begin{array}{l}\text { Adjustable } \\
\text { Height }\end{array}$ & $\begin{array}{c}2,500 \mathrm{~mm} \\
\text { (maximum) }\end{array}$ & $\begin{array}{c}\text { Programmable / } \\
\text { Adjustable Height }\end{array}$ \\
\hline 4. & $\begin{array}{l}\text { Loading } \\
\text { Capacity }\end{array}$ & $\begin{array}{c}1200 \mathrm{~kg} \\
\text { (maximum) }\end{array}$ & $\begin{array}{l}\text { Inclusive of baseplate, } \\
\text { jig, DUT and Operator } \\
\text { (SF: } 1.25)\end{array}$ \\
\hline 5. & Mass & & $\begin{array}{l}\text { Flooring requirement: } \\
\text { Can withstand max load } \\
\text { of } 10 \text { ton (TBC) }\end{array}$ \\
\hline 6. & Material & & $\begin{array}{l}\text { Need to consider } \\
\text { supported weight, } \\
\text { electrostatic discharge } \\
\text { and compatible with } \\
\text { cleanroom environment }\end{array}$ \\
\hline 7. & Wheel Type & $\begin{array}{l}\text { Polyamide wheels } \\
\text { or non-marking } \\
\text { tyres or any other } \\
\text { type of wheels } \\
\text { suitable for } \\
\text { cleanroom } \\
\text { operation }\end{array}$ & \\
\hline 8. & $\begin{array}{l}\text { Structural } \\
\text { rigidity, } \\
\text { stability and } \\
\text { balance }\end{array}$ & & $\begin{array}{l}\text { All design specification } \\
\text { to be supported FEA } \\
\text { Analysis, CAD Model, } \\
\text { Detail / Manufacturing } \\
\text { Drawing, Bill of } \\
\text { Material }\end{array}$ \\
\hline 9. & Finishing & & \\
\hline
\end{tabular}

TABLE II. CONTROL MECHANISM

\begin{tabular}{|c|c|c|}
\hline No. & Parameter & Specification \\
\hline 1. & $\begin{array}{l}\text { Movement } \\
\text { Mechanism }\end{array}$ & $\begin{array}{c}\text { Telescopic } \\
\text { Up/Down } \\
\text { Forward/Backward }\end{array}$ \\
\hline 2. & Transition Speed & $\begin{array}{c}\text { Telescopic: } \\
\text { Single Speed: } 0.25 \mathrm{~m} / \mathrm{min} \\
\text { Up/Down: } \\
\text { Slow Speed: } 0.25 \mathrm{~m} / \mathrm{min} \\
\text { Fast Speed: } 0.5 \mathrm{~m} / \mathrm{min} \\
\\
\text { Forward/Backward: } \\
\text { Slow Speed: } 0.25 \mathrm{~m} / \mathrm{min} \\
\text { Fast Speed: } 5.0 \mathrm{~m} / \mathrm{min}\end{array}$ \\
\hline 3. & $\begin{array}{c}\text { Acceptable } \\
\text { Vibration Range }\end{array}$ & $\begin{array}{l}\text { There should be NO SHOCK introduced to } \\
\text { the DUT. Subsequently, there should be no } \\
\text { jerking if the stop button is pressed. }\end{array}$ \\
\hline 4. & Controller & To be proposed \\
\hline 5. & Guidance & $\begin{array}{ll}\text { - } & \text { Intelligence guidance for parking } \\
\text { - } & \text { Intelligence guidance for alignment of } \\
\text { extended beam } \\
\text { - } \quad \text { Allow manual override }\end{array}$ \\
\hline 6. & $\begin{array}{l}\text { Emergency } \\
\text { Button }\end{array}$ & $\begin{array}{ll} & \text { Single emergency button } \\
\text { - } & \text { Emergency button provided at } 2 \\
\text { location }\end{array}$ \\
\hline 7. & Control Panel & To be proposed \\
\hline 8. & Operating Power & Battery operated \\
\hline
\end{tabular}

The design requirements were discussed and reviewed several times in different review meetings before all parties agreed to it. The design concept for MAVeP was developed from available systems such as the crane, forklift, single scissor lift, double scissor lift and hydraulic power lift before finally coming up with the design concept as shown in Fig. 1 below.

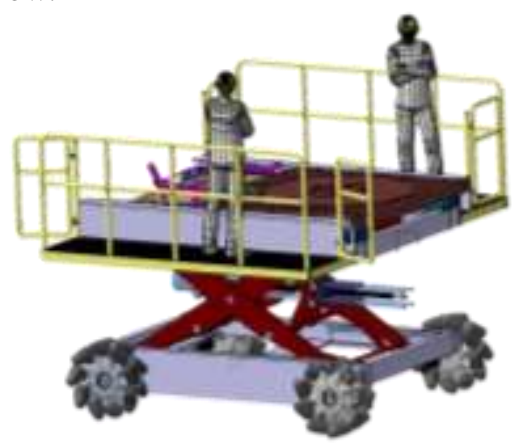

Figure 1. MAVeP design concept

Another notable design improvement of MAVeP compared to other mobile trolley was the introduction of mecanum wheels that allow for in-place rotation with minimal ground friction and low torque. These wheels are the answer to the problem of limited space for MAVeP movement in the facility, however the cost is much higher as compared to normal polyamide wheels. The concept of mechanical locking, taken from the existing multi-purpose trolley, was also added into the design of MAVeP.

As for the control system, IIUM has come up with an overall control system process that will be able to control the platform's functionalities. Fig. 2, 3 and 4 show the overall control system process, baseplate loading and baseplate unloading proces.

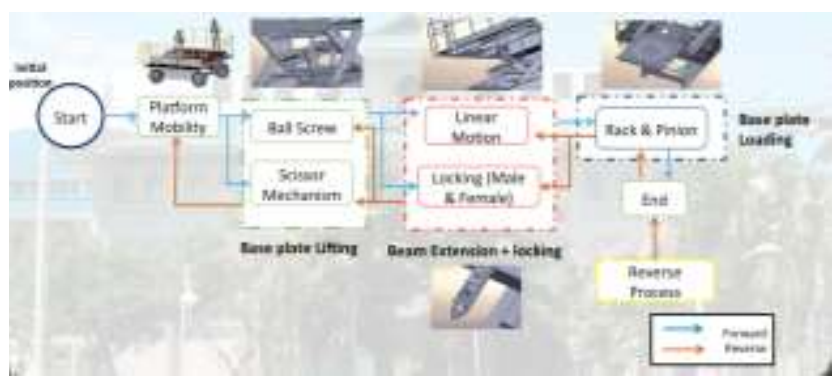

Figure 2. Overall control system process

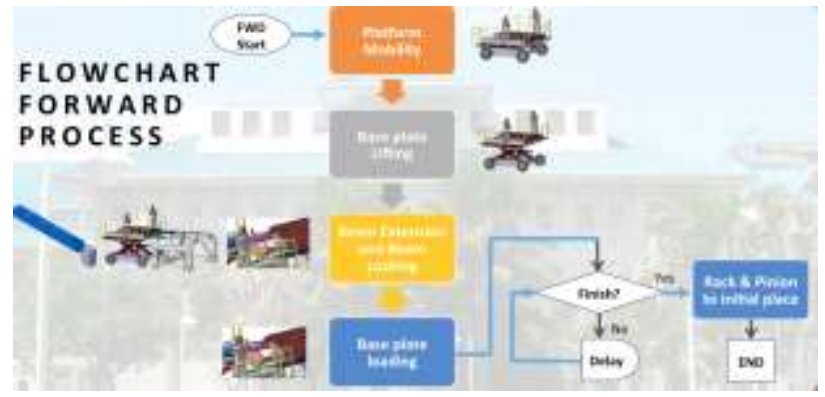

Figure 3. Baseplate loading process 
Proc. of The Fifth Intl. Conf. On Advances in Mechanical, Aeronautical and Production Techniques - MAPT 2016 Copyright (C) Institute of Research Engineers and Doctors, USA .All rights reserved.

ISBN: 978-1-63248-090-3 doi: 10.15224/ 978-1-63248-090-3-49

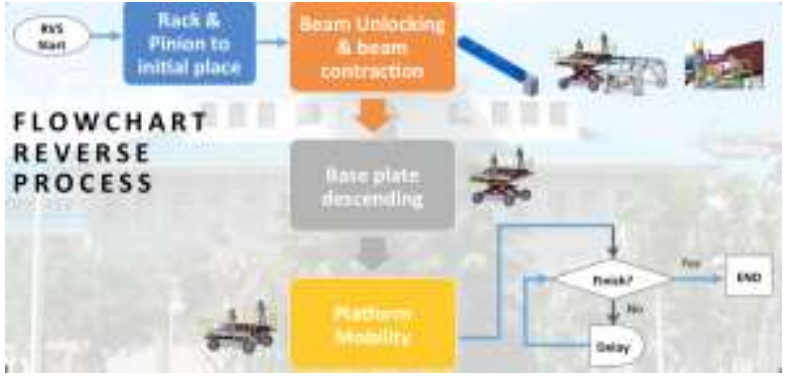

Figure 4. Baseplate unloading process

\section{Analysis of Results}

\section{A. Structure Platform}

The MAVeP structure platform is divided into three (3) modules: (i) the Base Module; (ii) the Scissor Arm Module; and (iii) the Deck Module. The bottom part of MAVeP is called the Base Module, the lifting part of MAVeP is the Scissor Arm Module and Deck Module covers the upper platform where the operator, baseplate and the satellite will be located. The figure of the base module, scissor arm module and deck module is as shown in Fig. 5, 6 and 7 below.

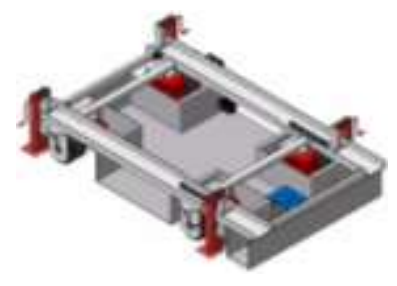

Figure 5. Base Module

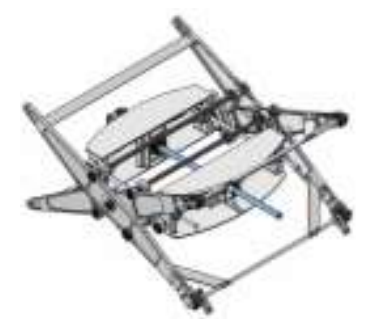

Figure 6. Scissor Arm Module

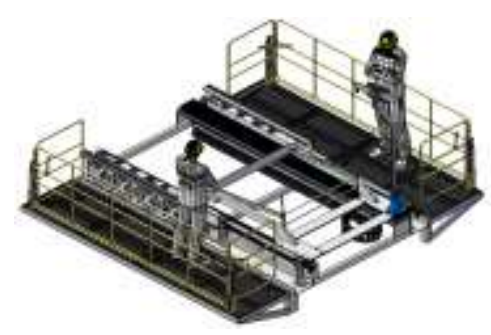

Figure 7. Deck Module

The primary structure of MAVeP has been designed to carry a one (1) tonne load consisting of the satellite, the base plate, adapter, maximum of two (2) operators, all secondary structures, control boxes, gear boxes, batteries, motors, sensors and other accessories. The load used in the analysis are of the type concentrated load, pressure load and surface traction load setup. Standard steel is selected as the material for all primary structure and any contacted surface between two structures are assumed to have zero $\mathrm{x}-, \mathrm{y}-$ and $\mathrm{z}-$ displacements.

Structural analysis was performed on the primary structure of MAVeP to determine the reaction forces, maximum stress, deformations and worst-case safety factor. SIRIM Berhad, led by Ir. Rohaizat Omar, performed the analysis based on the assembly drawing of MAVeP. The total weight of the structure is approximately $3500 \mathrm{~kg}$ with contingency. Structural verification was performed using a combination of hand calculations and finite element analysis using ABAQUS and CATIA Workbench. The maximum Von-Mises Stress allowed for the primary structure is 125 Mpa, corresponding to the safety factor of 2 , and exceeding the required safety factor of 1.25. The stress and displacement result is as shown in Table III below.

TABLE III. MAVEP STRESS ANALYSIS

\begin{tabular}{|c|c|c|c|}
\hline Component & $\begin{array}{c}\text { Maximum } \\
\text { Displacement } \\
\text { (mm) }\end{array}$ & $\begin{array}{c}\text { Maximum } \\
\text { Von-Mises } \\
\text { Stress } \\
\text { (MPa) }\end{array}$ & $\begin{array}{c}\text { Safety } \\
\text { Factor }\end{array}$ \\
\hline $\begin{array}{c}\text { Base Structure Assembly } \\
\text { (highest deck position) }\end{array}$ & 0.253 & 58.7 & 2.2 \\
\hline $\begin{array}{c}\text { Base Structure Assembly } \\
\text { (middle deck position) }\end{array}$ & 0.0505 & 21.16 & 6.1 \\
\hline $\begin{array}{c}\text { Base Structure Assembly } \\
\text { (lowest deck position) }\end{array}$ & 0.1145 & 37.71 & 3.5 \\
\hline $\begin{array}{c}\text { Base Structure } \\
\text { (highest deck position) }\end{array}$ & 0.6 & 90.55 & 1.4 \\
\hline $\begin{array}{c}\text { Base Structure } \\
\text { (middle deck position) }\end{array}$ & 0.1032 & 40.78 & 3.19 \\
\hline $\begin{array}{c}\text { Base Structure } \\
\text { (lowest deck position) }\end{array}$ & 0.0982 & 35.11 & 3.7 \\
\hline $\begin{array}{c}\text { Scissors } \\
\text { (highest position) }\end{array}$ & 1.644 & 101.76 & 2.3 \\
\hline $\begin{array}{c}\text { Scissors } \\
\text { (lowest position) }\end{array}$ & 1.992 & 137.23 & 1.7 \\
\hline $\begin{array}{c}\text { Extended beam } \\
\text { (not connected to } \\
\text { female) }\end{array}$ & 0.73 & 36.33 & 3.6 \\
\hline $\begin{array}{c}\text { Extended beam } \\
\text { (connected to female) }\end{array}$ & 0.02 & 10.19 & 12.8 \\
\hline $\begin{array}{c}\text { Deck } \\
\text { I Beam Base Plate } \\
\text { Support }\end{array}$ & 0.326 & 23.72 & 5.5 \\
\hline $\begin{array}{c}\text { Wheel Sliding Rail } \\
\text { (highest deck position) }\end{array}$ & 0.00045 & 3.603 & 65.1 \\
\hline $\begin{array}{c}\text { Wheel Sliding Rail } \\
\text { (middle deck position) }\end{array}$ & 0.00045 & 3.595 & 65 \\
\hline $\begin{array}{c}\text { Wheel Sliding Rail } \\
\text { (lowest deck position) }\end{array}$ & 0.00046 & 3.649 & 64 \\
\hline $\begin{array}{c}\text { Ratchet } \\
\text { (mone }\end{array}$ & 0.0086 & 50.91 & 4.56 \\
\hline
\end{tabular}

Some results of stress analysis conducted using CATIA are as shown in Fig. 8, and 9 below. 
Proc. of The Fifth Intl. Conf. On Advances in Mechanical, Aeronautical and Production Techniques - MAPT 2016 Copyright (c) Institute of Research Engineers and Doctors, USA .All rights reserved.

ISBN: 978-1-63248-090-3 doi: 10.15224/ 978-1-63248-090-3-49

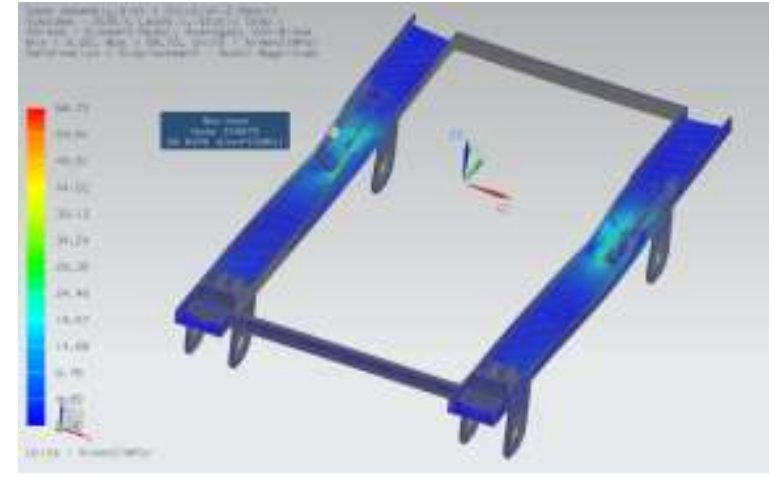

Figure 8. Maximum Von-Mises Stress 58.70 MPa for Base Structure Assembly

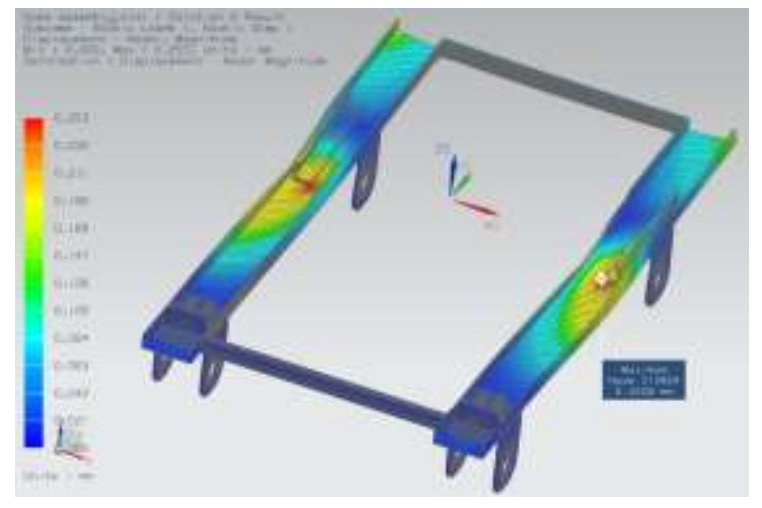

Figure 9. Maximum Displacement of $0.253 \mathrm{~mm}$ for Base Structure Assmebly

To determine the stability of MAVeP, the analysis was done on the centre of gravity of MAVeP. The following Fig. 11 gives an example of MAVeP plane view in relation to the centroid origin while Table IV provides the calculations of centre of gravity from centroid origin in three (3) positions.

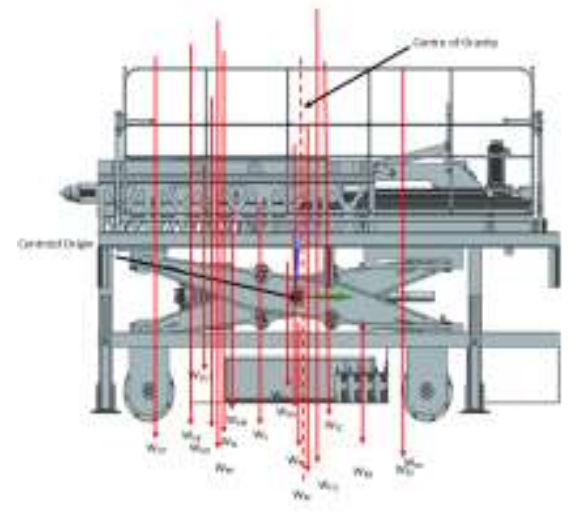

Figure 10. MAVeP at Lowest Position (YZ Plane View)

TABle IV. Calculation of MAVEP Stability

\begin{tabular}{|c|c|c|c|}
\hline Position & $\begin{array}{c}\mathbf{C G}_{\mathbf{X}} \\
(\mathbf{m m})\end{array}$ & $\begin{array}{c}\mathbf{C G}_{\mathbf{Y}} \\
(\mathbf{m m})\end{array}$ & $\begin{array}{c}\mathbf{C G}_{\mathbf{Z}} \\
(\mathbf{m m})\end{array}$ \\
\hline $\begin{array}{c}\text { Fully Elevated } \\
\text { Position }\end{array}$ & -14.79 & 223.04 & 642.69 \\
\hline $\begin{array}{c}\text { Fully Elevated and } \\
\text { Extended Position }\end{array}$ & -14.79 & 78.36 & 642.69 \\
\hline $\begin{array}{c}\text { Partial Elevated } \\
\text { Position }\end{array}$ & -14.79 & 79.00 & 507.59 \\
\hline Rest Position & -14.79 & 38.06 & 363.87 \\
\hline \multicolumn{3}{|l|}{}
\end{tabular}

\section{B. Control System}

The design and analysis of the control system includes the following processes: (i) mobility control; (ii) parking control; (iii) baseplate loading control; (iv) lifting mechanism; (v) telescopic or beam extension function; and (vi) locking mechanism. The torque is calculated for highest and lowest position using structural analysis method. At the highest position, the torque is $267.86 \mathrm{Nm}$, where else at the lowest position, the torque calculated was $594.839 \mathrm{Nm}$. Based on the torque calculations, the suitable motors for MAVeP were selected. During Critical Design Review (CDR) session, it was agreed that the original fast speed requirement of $20.0 \mathrm{~m} / \mathrm{min}$ for mobility is drop, as the battery-operated motor to support this requirement is too expensive. As for motion analysis, Table 5 below shows the expected time of arrival based on the speed requirement for each motion.

TABLE V. MOTION ANALYSIS OF MAVEP

\begin{tabular}{|c|c|c|c|c|}
\hline Motion & $\begin{array}{c}\text { Speed } \\
\text { Requirement } \\
(\mathrm{m} / \mathrm{min})\end{array}$ & $\begin{array}{l}\text { Motor } \\
\text { Speed } \\
(\text { rpm }) \\
\end{array}$ & $\begin{array}{l}\text { Torque } \\
\text { (Nm) }\end{array}$ & $\begin{array}{l}\text { Time of } \\
\text { Arrival }\end{array}$ \\
\hline \multirow[t]{2}{*}{$\begin{array}{l}\text { Forward / } \\
\text { Backward }\end{array}$} & $\begin{array}{c}\text { Fast Speed: } \\
5.0 \mathrm{~m} / \mathrm{min}\end{array}$ & 3.901 & $\begin{array}{l}2647.95 \\
\text { (per } \\
\text { motor) }\end{array}$ & - \\
\hline & $\begin{array}{c}\text { Slow Speed: } \\
0.25 \mathrm{~m} / \mathrm{min}\end{array}$ & - & - & - \\
\hline \multirow[t]{2}{*}{$\begin{array}{l}\text { Up } \\
\text { Down }\end{array}$} & $\begin{array}{c}\text { Fast Speed: } \\
0.5 \mathrm{~m} / \mathrm{min}\end{array}$ & 7 & 764.43 & $\begin{array}{l}2 \text { minutes } 06 \\
\text { second }\end{array}$ \\
\hline & $\begin{array}{c}\text { Slow Speed: } \\
0.25 \mathrm{~m} / \mathrm{min}\end{array}$ & 3.38 & 764.43 & $\begin{array}{l}4 \text { minutes } 23 \\
\text { second }\end{array}$ \\
\hline $\begin{array}{l}\text { Telescopic } \\
\text { (Extended } \\
\text { Beam) } \\
\end{array}$ & $\begin{array}{c}\text { Slow Speed: } \\
0.25 \mathrm{~m} / \mathrm{min}\end{array}$ & 1.324 & $0.8345 \mathrm{Nm}$ & $\begin{array}{l}6 \text { minutes } 15 \\
\text { seconds }\end{array}$ \\
\hline Locking & - & & 0.8345 & - \\
\hline $\begin{array}{l}\text { Baseplate } \\
\text { Loading }\end{array}$ & $\begin{array}{c}\text { Slow Speed: } \\
0.25 \mathrm{~m} / \mathrm{min}\end{array}$ & 1.324 & 19.683 & - \\
\hline
\end{tabular}

\section{Conclusion}

In this paper, the design requirements and design specification has been discussed and presented. Based on the design requirements, the conceptual design of MAVeP was presented. From the conceptual design, a more detailed design was developed, and from this detailed design, the structural, torque and motion analysis results were calculated and presented in this paper. From the analysis results, it is noted that the detailed design of MAVeP has met the requirements set out, and is well within the safety margin.

The next milestone for this project will be manufacturing and assembly process, which is expected to complete by $2^{\text {nd }}$ quarter of this year.

\section{Acknowledgment}

We would like to express our gratitude our DirectorGeneral of ANGKASA, Dr. Noordin Ahmad for leading and supporting this project, and to Ministry of Science, Technology and Innovation (MOSTI) for providing research grant to fund the project. We also like to thank the entire project team of ANGKASA, University Putra Malaysia, International Islamic University of Malaysia and SIRIM 
Proc. of The Fifth Intl. Conf. On Advances in Mechanical, Aeronautical and Production Techniques - MAPT 2016

Copyright (C) Institute of Research Engineers and Doctors, USA .All rights reserved.

ISBN: 978-1-63248-090-3 doi: 10.15224/ 978-1-63248-090-3-49

Machinery Technology Centre who had contributed in this project one way or another.

\section{References}

[1] E.W.L Leng, M. Ismail, M.D. Subari, "Setting-up the Assembly, Integration and Test Centre in Malaysia", 2009, pp. 452 - 458

[2] E. Perl, T. Do, A. Peterson and J. Welch, "Environmental Testing for Launch and Space Vehicles", vol. 6

[3] S.S Lee, S.W Choi, H.B Kim, and Z.C Kim, "KARI's Testing Facilities and Technologies for GEO Satellite Development", vol. 76, 2002, pp. $71-76$

[4] E.W.L Leng, N. Salleh, H. Salim, S.F Sabri, M. Ismail, "Design and Development of Motorised Adjustable Vertical Platform for Satellite Test Facility", 2015

About Author (s):

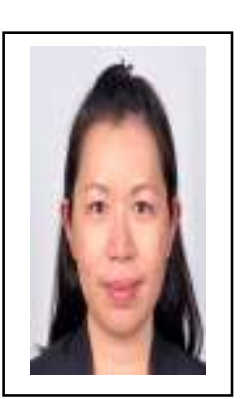

Elena Woo graduated with a MSc. in

Computer Science from University

Technology of Malaysia and has been with ANGKASA since 2005. She has been involved in the AITC project from the beginning, and is now overseeing the management and operation of AITC. She is also involved in the project of Designing and Developing a Motorized Adjstable Vertical Platform (MAVeP) from the beginning. 